\title{
The (Early) Search for Missing Nazi Victims
}

\author{
Historical Precedents, Organizational Frameworks, and \\ Methods
}

\begin{abstract}
This chapter aims mainly to provide an overview of the early history of the search for victims of Nazi persecution from 1944 to the early 1950s (though an outlook regarding later developments will also be provided). At the core of this increasingly centralized process was the creation of the International Tracing Service (ITS) - later to become the Arolsen Archives - by the Allies. The focus will be on the organizational framework of tracing and documenting based on historical precedents while also looking at the use of different methods that were devised by the Allies for the sake of clarifying individual fates of Nazi victims during this time. These have, to date, received little attention from historians.
\end{abstract}

\section{Introduction}

In 1943, on behalf of the International Labor Office, Russian-American sociologist Eugene M. Kulischer authored The Displacement of Population in Europe. A seminal work in the context of preparing the world community for a new post-war order, it analyzed the myriad instances of civilian mass migration in Europe against the background of the Second World War. Refugees, evacuees, deportees, prisoners, forced laborers: how many individuals - both German and non-German - could the Allies expect to find outside their home countries by the end of the war? Kulischer, using as much statistical material as was available at the time, calculated that a staggering 30 to 40 million individuals would be in need of humanitarian support in order to facilitate their repatriation or resettlement. $^{1}$

However, despite his mathematical determination, Kulischer cautioned that the events of the war were still ongoing and, for now, rendered any definite assessment of future challenges impossible:

1 Eugene M. Kulischer: The Displacement of Population in Europe, Montreal: International Labor Office, 1943, 176-177. Available at: https://archive.org/details/displacementofpo031323mbp/ page/n3. Last accessed: 26.7.2019.

Ә OpenAccess. (C) 2020 Christian Höschler, Isabel Panek, published by De Gruyter. (cc) BY-NC-ND This work is licensed under the Creative Commons Attribution-NonCommercial-NoDerivatives 4.0 License. 
It is obvious that the number and whereabouts of all those who will have to be redistributed and resettled cannot be determined until the war is over. For the time being, every passing month merely complicates the problem still further. Workers are being snatched from their homes in thousands and tens of thousands; families are disintegrated; whole groups are separated from their national community and scattered or regrouped in distant places. $^{2}$

What Kulischer predicted, then, was unprecedented migratory chaos - a challenge, as the author noted, that could only be solved through a coordinated effort at the international level. ${ }^{3}$

In retrospect, these assumptions proved to be true. During the immediate post-war years, the Allies felt overwhelmed by the challenges they encountered on a continent in disarray. The liberation and (partial) occupation of Europe, the urgent task of supplying food, goods and shelter to populations devastated by the final chapter of the war, all of this constituted a monumental task in its own right. Then there was the care for millions of survivors of Nazi persecution, the so-called Displaced Persons (DPs). They had been defined by the Allies as "civilians outside the national boundaries of their country by reason of war" and "desirous but unable to return home or find homes without assistance". ${ }^{4}$ Essentially, the DPs were the former forced laborers, concentration camp inmates, and other victims of Nazi crimes, now scattered across all of Europe, but mainly situated within the territories of the defeated German Reich. ${ }^{5}$

The search for missing persons was of utter urgency and importance not only to those who had endured persecution, but also to their friends and families, as well as the governments of countries who were now determined to have their citizens return, not least for the sake of post-war reconstruction. However, in the immediate months following the end of the war, there was no single and coordinated effort to organize the search for the missing, or the gathering of relevant information necessary to perform this task. As a result, a broad spectrum of individual activists, small initiatives and well-established organizations formed the basis for early tracing and documentation. Characterizing this as a

2 Ibid., i.

3 Ibid., 171.

4 Administrative Memorandum 39: Displaced Persons and Refugees in Germany, 18.11.1944, WO 204/2869, The National Archives, Kew.

5 As an introduction to the topic of DPs in post-war Europe, see Mark Wyman: DP: Europe's Displaced Persons, 1945-1951, Philadelphia: Balch Institute Press, 1989. The most important overview published in German remains Wolfgang Jacobmeyer: Vom Zwangsarbeiter zum Heimatlosen Ausländer: Die Displaced Persons in Westdeutschland 1945-1951, Göttingen: Vandenhoeck \& Ruprecht, 1985. 
flaw of Allied planning, historian Jenny Edkins has aptly pointed to the "disorder of tracing services" as a reflection of the "'primeval Chaos' into which the European continent had dissolved". ${ }^{6}$ Eventually, from the late 1940 s onward, the Allies put more centralized frameworks and procedures into place. Going hand in hand with this was the rapid development and sometimes improvised use of different strategies in the search for missing individuals. Finally, with varying needs regarding tracing and documentation emerging in different phases of the postwar era, the nature of this work changed considerably over time.

\section{Historical Precedents of Tracing and Documentation}

The Second World War, while unparalleled in its specific events, was not the first crisis that resulted in large-scale search operations regarding missing individuals. Hence, the professional field of search and documentation was also not a tabula rasa. At the beginning of the First World War, the International Committee of the Red Cross (ICRC) in Geneva founded the International Prisoners-of-War Agency, probably the most significant institution of its kind to play a formative role in this field. The organization's task was to provide a central point of enquiry regarding missing individuals from all belligerent states. It rendered its services to military personnel and civilians alike, e.g. by documenting the current location of POWs or wounded soldiers, as well as casualties in the theatre of war. This information was forwarded to family members seeking reassurance regarding the current whereabouts and/or health of their loved ones. ${ }^{7}$ Pioneering methods - such as the creation of a name index referring to relevant materials within other collections, e.g. lists of POWs who found themselves displaced throughout camps all over the world - drew heavily upon the support of volunteers. ${ }^{8}$

There are irrefutable similarities between the activities of the ICRC at the time and the work of institutions that would later play a central role in tracing after the Second World War. As we shall see in a later portion of this chapter,

6 Jenny Edkins: Missing: Persons and Politics, Ithaca: Cornell University Press, 2016, 59.

7 For a brief overview, see International Committee of the Red Cross: The International Prisoners-of-War Agency: The ICRC in World War One, Geneva: International Committee of the Red Cross, 2017. Available at: https://www.icrc.org/en/doc/assets/files/other/icrc_002_0937.pdf. Last accessed: 26.7.2019.

8 Gradimir Djurović: The Central Tracing Agency of the International Committee of the Red Cross, Geneva: Henry Dunant Institute, 1986, 43-48. 
knowledge transfer would eventually even take place at the staff level. Still, historical research has yet to investigate in more detail to what extent experiences gained in previous conflicts actually had an impact on challenges of a similar nature in the immediate years following the defeat of the Nazis.

\section{Neither Silent nor Passive: The Role of Survivors}

In recent years, historians like Laura Jokusch ${ }^{9}$ have challenged the long-held notion that survivors of Nazi persecution remained silent and/or passive objects after liberation and the end of the Second Wold War. There is ample proof that the very opposite was the case, with survivors such as Simon Wiesenthal launching their own initiatives ${ }^{10}$ to document Nazi crimes.

Managing records pertaining to Nazi persecution was not only important in terms of chronicling historical events. Instead, information about the atrocities committed by the Germans also became a decisive resource in a different context: the search for, and provision of information about, missing victims of Nazi persecution. Again, survivors played a crucial role in this. As we shall discuss in more detail later, the Allies had underestimated and subsequently felt overwhelmed by the scale of Nazi persecution. Because of this, they failed to prepare sufficiently for the task of tracing missing individuals while the war was still ongoing. However, many of those who themselves had witnessed and endured the crimes committed by the Nazis took matters into their own hands by actively engaging in and hence shaping the field of postwar tracing and documentation. Some did this by joining pre-existing relief organizations that were now involved in the search for missing persons. For instance, the American Jewish Joint Distribution Committee (AJDC), with its own global network of offices processing search cases at the international level, employed Holocaust survivors for this very task. ${ }^{11}$ For a long time, post-war historiography has neglected such activities. In recent years they have started to enter into the wider collective memory, too. ${ }^{12}$

9 Laura Jockusch: Collect and Record! Jewish Holocaust Documentation in Early Postwar Europe, Oxford: OUP, 2012.

10 See, for example, the chapter by René Bienert on Simon Wiesenthal in this volume.

11 See the chapter by Linda Levi in this volume.

12 For example, a 2019 exhibition produced by the Wiener Library in London documented the tireless zeal of various Holocaust survivors to assemble evidence regarding the hitherto unparalleled crimes of the Nazis and support the legal prosecution of individual perpetrators. The exhibition featured, among other individuals, Emmanuel Ringelblum and Rachel Auerbach, 
A particular case in point, which we will explore in more detail here, is that of the International Information Office (IIO) in Dachau, Germany. This initiative came into existence in early October 1945, i.e. five months after US troops had liberated the camp during the final days of the war. While the IIO was a newly created body with its own specific agenda, it did fit into a pre-existing structure of self-governance that former inmates had established on the grounds of the camp, all under the jurisdiction and protection of the American occupational forces. The activities of the IIO were manifold: on the one hand, the office supported former prisoners and their families by arranging for donations as well as the provision of clothing, food tickets and other goods that they desperately needed during the post-war struggle. On the other hand, going beyond material aid, the IIO also provided a growing number of enquirers with information about individual inmates of the Dachau concentration camp. The IIO also issued certificates of imprisonment. For this purpose, staff members of the IIO (who were former prisoners themselves) drew upon official SS records that the Germans had failed to remove or destroy before the liberation of the camp. ${ }^{13}$ Among these were registration forms for individual prisoners containing a variety of information, such as personal details, arrival and release dates, reasons for arrest and incarceration, and more. ${ }^{14}$ While the IIO exerted a degree of agency that may seem surprising in that it defies the previously held conception of helpless victims, ${ }^{15}$ the work of the former prisoners in Dachau did in fact have its limitations. What illustrates this well is the correspondence surrounding one particular case in the summer of 1946. Ilse Voigt, a German national, had previously received a certificate from the IIO, showing that her father, Otto Riebe, had previously been a prisoner of the Dachau concentration camp. However, this information was not enough for her. She penned a follow-up letter to the IIO asking for the exact reason why the Nazis had arrested her father. In this letter Voigt indicated that in

known for creating and preserving a clandestine archive documenting everyday life within the Warsaw Ghetto. For more information, see The Wiener Library: Crimes Uncovered: The First Generation of Holocaust Researchers. Available at: https://www.wienerlibrary.co.uk/crimes-un covered. Last accessed: 26.7.2019.

13 Sebastian Schönemann: "Das Namensregister als Zeugnis: Zur kommemorativen Funktion früher Überlebenden-Suchdienste”, in Rebecca Boehling, Susanne Urban and René Bienert (eds.): Freilegungen: Überlebende - Erinnerungen - Transformationen, Göttingen: Wallstein, 2013, 201-203.

14 For more information on the scope of individual concentration camp records and the information they provide, see Arolsen Archives: e-Guide. Available at: https://eguide.arolsen-ar chives.org. Last accessed: 26.7.2019.

15 Katharina Stengel and Werner Konitzer (eds.): Opfer als Akteure: Interventionen ehemaliger NS-Verfolgter in der Nachkriegszeit, Frankfurt/New York: Campus Verlag, 2008. 
the past she had been subject to some sort of political ostracism surrounding her father's persecution. ${ }^{16}$ Polish national Walter Cieślik, a former political prisoner of the Dachau concentration camp who at the time was head of the IIO, ${ }^{17}$ replied to Voigt that he did not have authorization to provide her with this information. Only the local municipal concentration camp prisoner support office ( $K Z$ - Betreuungsstelle) responsible for Voigt was entitled to enquire about the details of her father's arrest. ${ }^{18}$ Ilse Voigt then quickly turned to the city of Rostock that dispatched its own request regarding Otto Riebe to Dachau. ${ }^{19}$ This resulted in the provision of the desired arrest reason, namely that the Nazis had imprisoned Otto Riebe on the grounds of police protective custody. ${ }^{20}$ This placed him within the group of so-called professional criminals, a victim group that was not eligible for relief services and faced continued discrimination for decades to come.

Although the Allies generally granted the IIO permission to perform its work, it was limited in terms of what information it could disclose. This may have been a means of negotiating authority on the part of the US authorities, and interestingly, the IIO ceased to exist as an independent unit in September 1946. Staff and records were incorporated into the Munich branch of the United Nations Relief and Rehabilitation Administration (UNRRA) tracing and documentation department. ${ }^{21}$ This too is an indicator of how highly the Allies regarded the tracing work carried out by survivors. However, at the same time, the Allies removed the survivors' autonomy in favor of an increasingly centralized process of tracing and documentation, as will become clear in the next section of this chapter.

Through its work, although only short-lived, the IIO became an integral part of the early search for missing individuals as carried out by those who had shared a similar fate at the hands of the Nazis. The correspondence of the IIO with both inquirers and other authorities, as well as the individual camp records the IIO used for its work, ultimately found their way into the collections of today's Arolsen Archives. The provision of information based on documents from

16 Letter from Ilse Voigt to the IIO, 12.6.1946, 1.1.6.0/82098503/ITS Digital Archive, Arolsen Archives.

17 Schönemann: Das Namensregister als Zeugnis, 202.

18 Letter from Walter Cieślik (IIO) to Ilse Voigt, 28.6.1946, 1.1.6.0/82098502/ITS Digital Archive, Arolsen Archives.

19 Inquiry from the Victims of Fascism Committee (Rostock City Council) to the IIO, 18.7.1946, 1.1.6.0/82098501/ITS Digital Archive, Arolsen Archives.

20 Response from Walter Cieślik (IIO), 12. 8.1946, 1.1.6.0/82098500/ITS Digital Archive, Arolsen Archives.

21 DaA A 2011/2.6.37/41983, Dachau Concentration Camp Memorial Site Archive. 


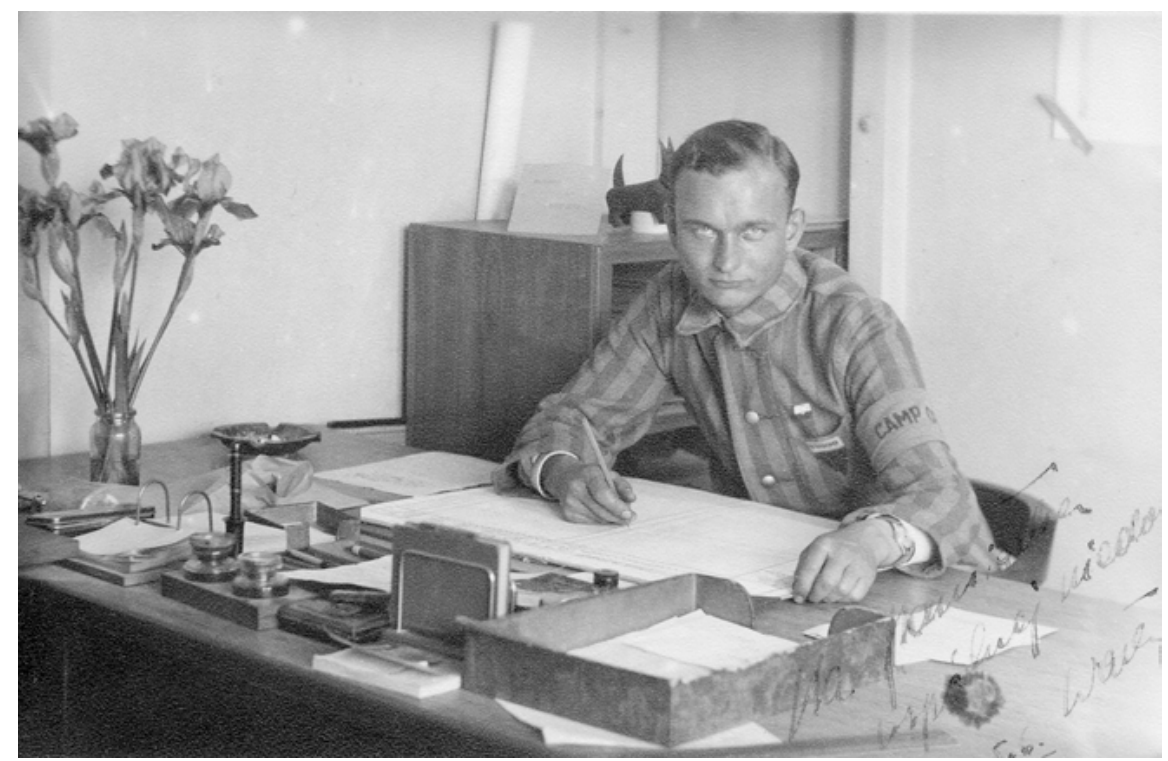

Fig. 1: Walter Cieślik, former Polish political prisoner of the Dachau concentration camp and head of the IIO, at his desk, 5.6.1945 (DaA F 1832/33281/KZ-Gedenkstätte Dachau)

the Dachau concentration camp thus builds, to this day, on the dedicated work that survivors of Nazi persecution performed in the aftermath of their own ordeal. ${ }^{22}$

\section{Creating Larger Structures: The Establishment of the International Tracing Service}

In terms of developing a centralized system - or, as it would initially come into existence, a coordinated network - of tracing in postwar Europe, the beginnings lie in the United Kingdom in 1944. This was where the European headquarters of UNRRA were located. Officials from the British Red Cross (BRC), representatives of the ICRC and UNRRA itself first discussed the issue of large-scale tracing activities to take place after the end of the war. ${ }^{23}$

22 Sub-collection 1.1.6.0: General Information on Dachau Concentration Camp, ITS Digital Archive, Arolsen Archives.

23 See the chapter by Christine Schmidt in this volume. 
Although it appeared evident that millions of people would be searching for millions of friends and relatives, the Supreme Headquarters, Allied Expeditionary Force (SHAEF), downplayed the importance of agreeing on an appropriate plan. Instead, the Allies prioritized military operations. They feared that the DPs (estimated to number around 11 million) would clog up roads and jeopardize the advance of Allied troops into mainland Europe. Preventing such circumstances was, from the point of view of SHAEF, more important than the anticipation of social human needs, i.e. enabling DPs to obtain information about missing loved ones. With the war still raging, the success of military efforts against Germany and the principle of limiting assistance to a bare minimum (shelter and food) was the priority. ${ }^{24}$

Because of this rather sobering outlook, larger tracing operations, for now, centered on the British Red Cross Foreign Relations Department. It increasingly processed inquiries from all liberated territories in Europe and dispatched staff into the field where they would actively search for missing persons and Nazi documents which might provide information about their whereabouts. ${ }^{25}$ Once the Allies realized how urgent the tracing issue was for DPs and others who were searching, they hastily devised a plan to set up a large tracing structure within occupied Germany in the summer of $1945 .{ }^{26}$ As a result, the Central Tracing Bureau (CTB) was established within the US Zone of Germany. UNRRA agreed to run the CTB in Frankfurt-Höchst, but this proved to be only an interim solution, for the CTB moved to Arolsen in Northern Hesse in January 1946. There were a number of reasons for the move, ${ }^{27}$ one of which was the fact that the premises in Frankfurt lacked adequate facilities and equipment. ${ }^{28}$ As a result, in terms of getting on with the tracing work, "progress was painfully slow". ${ }^{29}$ The chief mission of the CTB was

to search for missing [...] persons of United Nations nationalities and establish the fate of those who would not be found; to locate, collect and preserve all available records regard-

24 Edkins: Missing, $60-62$.

25 Ibid., 65-66.

26 Ibid., 67.

27 See Henning Borggräfe, Christian Höschler and Isabel Panek (eds.): A Paper Monument: The History of the Arolsen Archives, Exhibition Catalogue, Bad Arolsen: Arolsen Archives, 2019, $62-63$.

28 International Refugee Organization: Historical Survey of Central Tracing Activity in Germany, 1945-1951: The Tracing of Missing Persons in Germany on an International Scale with Particular Reference to the Problem U.N.R.R.A., Geneva: International Refugee Organization, 1951, 20 - 21. 29 Ibid., 21. 
ing refugees and displaced persons in Germany; and to serve as a link to bring interested persons into communication with each other. ${ }^{30}$

In reality this meant that the CTB joined a network of national tracing bureaus officially representing a number of different countries. ${ }^{31}$ These would forward search requests concerning their respective nationals to the CTB, which in turn went about processing the cases within occupied Germany. However, the СТВ never assumed a role as central as its name would have suggested, for the Allies also established tracing offices in the individual occupation zones in Germany, the so-called zonal tracing bureaus. They were the ones ultimately processing the inquiries and securing relevant records that would facilitate this work under the jurisdiction of the occupational authorities. ${ }^{32}$ The CTB, on the other hand, acted more as a clearinghouse for the enquiries, serving as a hub between the national tracing bureaus producing cases and the zonal tracing bureaus processing them in the field.

In early 1947 the International Refugee Organization (IRO) agreed to continue the tracing work in its role as successor agency to UNRRA. In preparing for the takeover, efforts were made to optimize the search for missing persons and thus solve some of the problems that the СТВ had been battling with because of the prevailing, decentral structure. The IRO formally assumed responsibility for the CTB and at the same time changed its name to International Tracing Service (ITS) at the beginning of $1948 .{ }^{33}$ The first director of the newly established ITS, the Swiss national Maurice Thudicum, had previously been involved in the reorganization process as a consultant to UNRRA and the IRO. His expertise was of particular value since he was a former senior staff member of the International Committee of the Red Cross (ICRC) in Geneva. Here, then, the link between historical precedents of tracing and the handling of new challenges after the Second World War became evident at the leadership level. The realignment of the work carried out by the ITS involved the step-by-step centralization of all activities in Arolsen.

30 The International Tracing Service, Brief Review of its History and Activities (Submitted by the Director-General), 16.3.1951, 6.1.1/82493196/ITS Digital Archive, Arolsen Archives.

31 This volume features two chapters by Christine Schmidt and Maren Hachmeister, dedicated to national postwar tracing activities in Great Britain as well as Poland and Czechoslovakia, respectively.

32 The International Tracing Service, Brief Review of its History and Activities (Submitted by the Director-General), 16.3.1951, 6.1.1/82493196/ITS Digital Archive, Arolsen Archives.

33 Edkins: Missing, 82. 


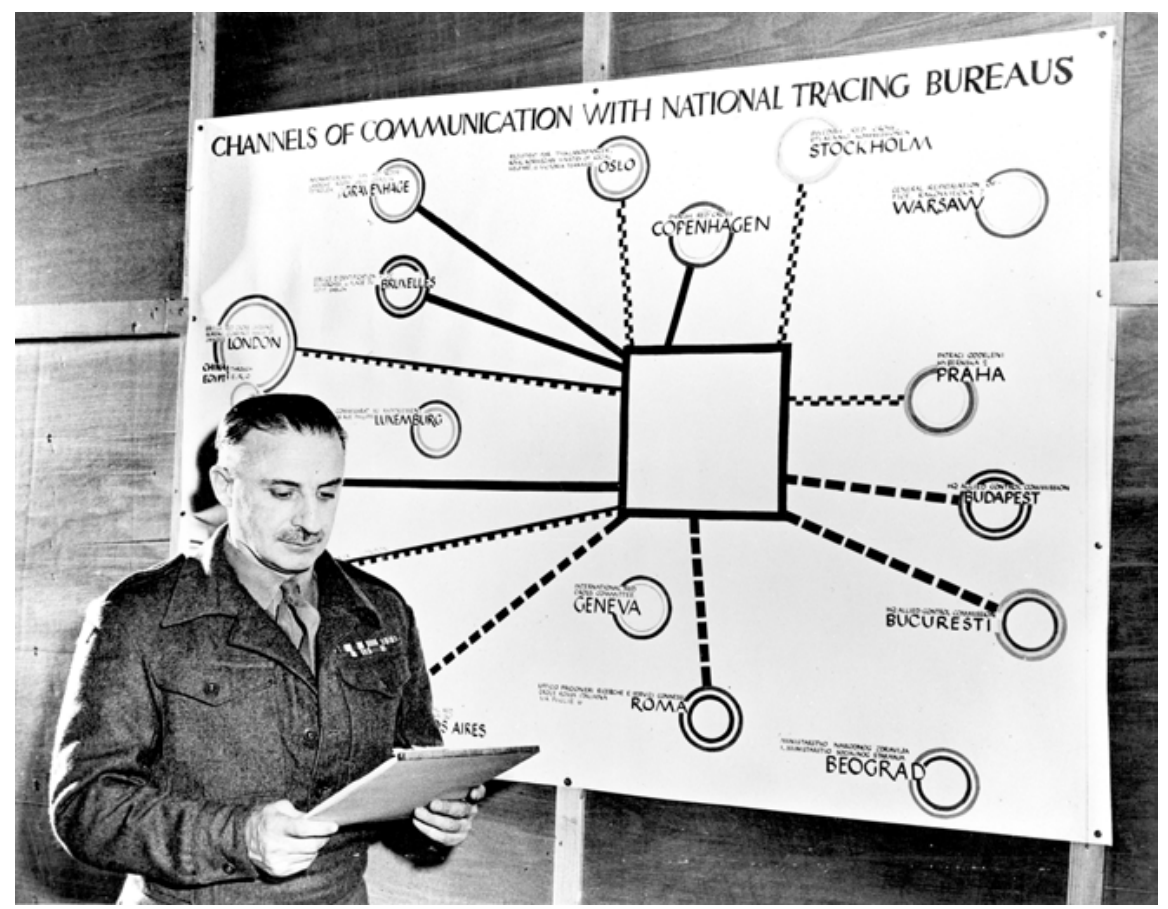

Fig. 2: John R. Bowring, head of the CTB, standing in front of a chart showing communication channels between the CTB and national tracing bureaus, Frankfurt-Höchst, 1945 (S-1058-0001-01-00082/United Nations Archives)

There, the ITS headquarters gradually became the central place for

all policy planning, liaison with NTB [National Tracing Bureaus] and tracing agencies, and the direction and supervision of zonal field offices, [...] individual tracing activities [...]; and the processing, distribution and preservation of documents from other agencies or collected in the field. ${ }^{34}$

In the end, the Allies closed the zonal tracing bureaus and transferred their respective staff and records to Arolsen. The Allies gathered the aforementioned documents, which became the archival collections of the ITS and today's Arolsen Archives, in multiple contexts. Some had been retrieved from liberated concentration camps or compiled through interrogations of Nazi perpetrators. Other ma-

34 The International Tracing Service, Brief Review of its History and Activities (Submitted by the Director-General), 16.3.1951, 6.1.1/82493197/ITS Digital Archive, Arolsen Archives. 
terials included lists of forced laborers created by local German authorities during the war, and records from the missions of UNRRA and the IRO, most notably the registration of individual DPs and paperwork regarding their repatriation or resettlement abroad. ${ }^{35}$ We will now look at how exactly the search for missing victims of Nazi persecution was organized by the CTB/ITS in the second half of the 1940s.

\section{The Search for Missing Persons in the Post-War Period: Methods and Challenges for the CTB and its successor, the ITS}

As described above, the ITS and its predecessor, the Central Tracing Bureau, were able to draw in part on knowledge and techniques that had previously been applied by other established tracing services, such as the ICRC or the AJDC, and use them for their own day-to-day work of tracing children, adolescents and adults. ${ }^{36}$ However, the Second World War was on a greater scale than any of the previous wars of the twentieth century and new tracing methods had to be developed to cope with the mass deportation, abduction and murder of millions of people. These methods were primarily derived from practical experience, from the need to act; they were tried out and developed further and some were then rejected. The following tracing methods soon established themselves at the CTB: a search in a Central Name Index (CNI) with related research in the documents on Nazi crimes that had been rescued, an active search in the field and cooperation with local authorities, and finally, mass tracing efforts utilizing the media.

Work on setting up a Central Name Index first started at the CTB in the autumn of 1945. This involved staff transferring all the important information contained in the tracing inquiries onto index cards, most particularly personal details and information about the fate of the persecutees. They then put the cards into alphabetical order and sorted them into the CNI. The idea was that

35 Ibid., 7-9. For more information on the creation of the archival collections and their contents, see the paper by Henning Borggräfe and Isabel Panek in this volume.

36 The present chapter concentrates on the search for adults. A special department was set up to trace children and adolescents, see Julia Reus: "'Everywhere where human beings are, we can find our children': On the Organization of the ITS Child Search Branch Files”, in Henning Borggräfe, Akim Jah, Steffen Jost, and Nina Ritz (eds.): Freilegungen: Rebuilding Lives - Child Survivors and DP Children in the Aftermath of the Holocaust and Forced Labor, Göttingen: Wallstein, 2017, 41-49. 


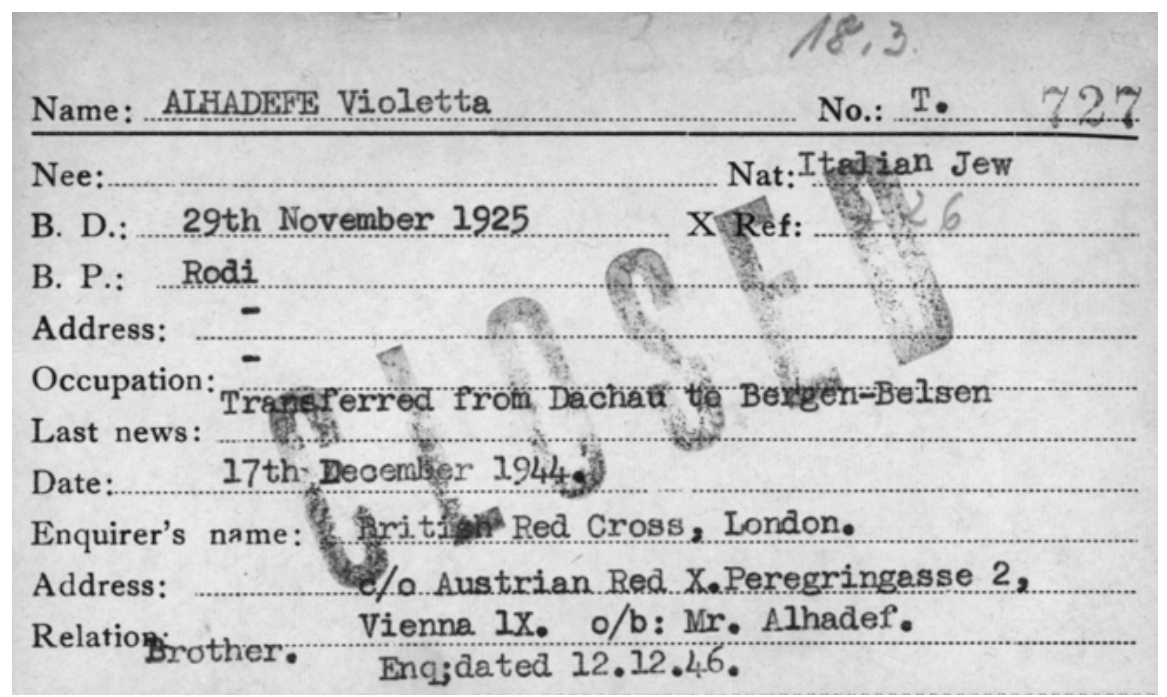

Fig. 3: Inquiry Card for Violetta Alhadefe, 1946 (0.1/13095518/ITS Digital Archive, Arolsen Archives)

the inquiry cards of people who were trying to trace others and the inquiry cards of those who were being traced would come together during this sorting process. At the ITS, this was known as a meeting of cards, as it subsequently enabled the tracing bureau to put both parties in touch with each other. However, meetings were only possible in a small number of cases, as many of those missing had not submitted an inquiry themselves or were no longer alive to do so. This is why the documents from the concentration camps and the records collected in connection with the Allies' efforts to trace foreign nationals constituted a second cornerstone for the creation of the Name Index. ${ }^{37}$ These documents contained information about a person's path of persecution and often provided clues as to the last location of a missing person. Starting in 1946, this type of personal information was also transferred to reference cards and these too were added to the CNI. This procedure continued for decades and was known at the ITS as carding.

Despite the fact that the inquiry cards and reference cards were filed alphabetically, mistakes were sometimes made when the cards were sorted and it was not uncommon for information to disappear without a trace. In order to make the card index less vulnerable to errors of this kind, an alphabetic-phonetic system was introduced in 1949. Previously used in the index of prisoners-of-

37 See the chapter by Henning Borggräfe and Isabel Panek in this volume. 


\section{1 \\ NAMES TOUND WDUCUMENTS}

PROOBSSBD BY I.T.S.

T O I LL $\quad 16,851,837$
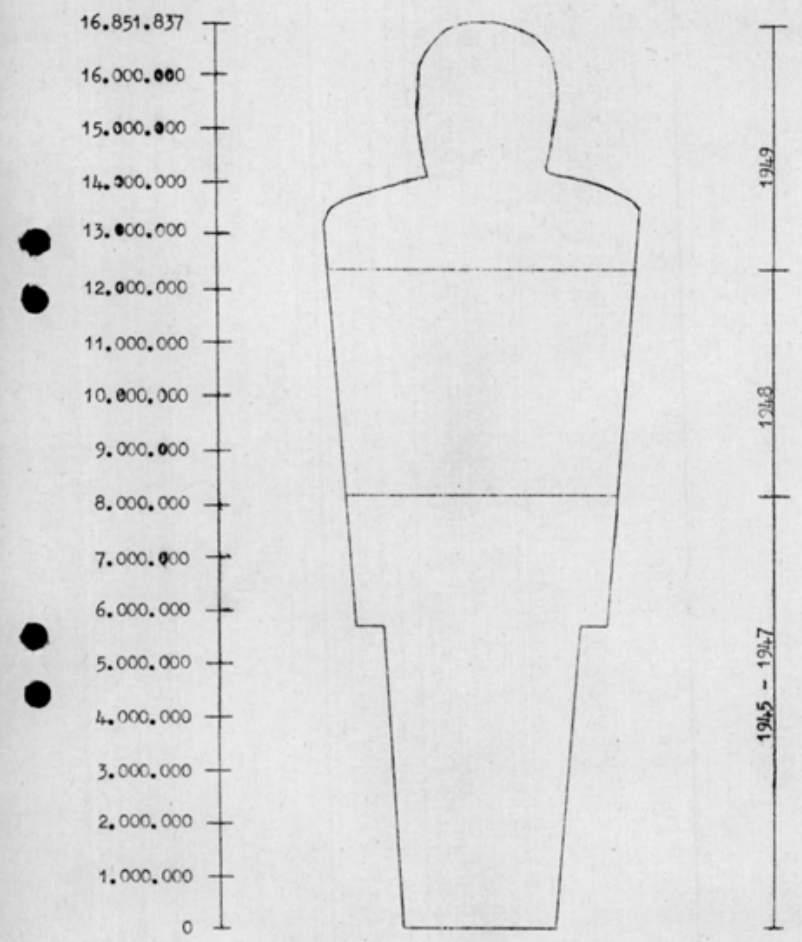

Fig. 4: The chart shows how many names were collected through "carding" from 1945 until 1949 (6.1.1/82505898/ITS Digital Archive, Arolsen Archives) 
war created by the ICRC in Geneva ${ }^{38}$, this new system took the pronunciation of names into account and provided a solution to the problems associated with the different variants and misspellings of names that often arose as a result of the many different nationalities of the victims of persecution registered by the Nazi authorities and of the DPs registered by Allied administrations. Regardless of how a name is written, all the reference cards pertaining to one and the same individual are filed together to this day. ${ }^{39}$ Implementation of the new sorting system began in May and was completed in the autumn of 1949. During the restructuring process, 20,000 previously unsolved inquiries could be answered. ${ }^{40}$ Parallel to their work on setting up the Name Index, staff also started to create other indexes. Separate indexes of this kind, each containing several million documents, exist for documents on Displaced Persons, forced laborers and concentration camp prisoners. This means that once a search has been made in the Name Index, other indexes also need to be consulted, as there are no references to the information they contain in the CNI. Because of the many steps involved, research was and is time consuming and prone to error. Cramped conditions were another challenge which affected day-to-day work with the Name Index in the early days: the index grew at a rate of several thousands of cards per month, from 1,976,499 cards in 1948 to over 10 million just two years later. ${ }^{41}$ Today, the CNI contains over 50 million reference cards on the fate of about 17.5 million individuals.

In 1947, in addition to carding the inquiries, staff in Arolsen also began to open a case file for each person being traced, these were known as $T$ files. The $T$ stood for tracing, the process of searching for a missing person. All the correspondence and research results concerning a person's fate were kept in these files. At the same time, staff used the covers of the files for an overview of all the steps which were taken in order to trace the person concerned: Action of Correspondence Section, Action of Records Branch, Field Trace, Map Location, Mass

38 The International Tracing Service, Brief Review of its History and Activities (Submitted by the Director-General), 16.3.1951, 6.1.1/82493200/ITS Digital Archive, Arolsen Archives.

39 For example, there are 849 different spellings of the surname Abrahamovic in the CNI.

40 The International Tracing Service, Brief Review of its History and Activities (Submitted by the Director-General), 16.3.1951, 6.1.1/82493200/ITS Digital Archive, Arolsen Archives.

41 At the beginning, the CTB, and its successor, the ITS, were not accommodated at a single, central location in Arolsen. Most of the facilities available were too small for the card indexes to be stored neatly on shelves. In 1949, following the move to the former barracks in Arolsen, the buildings which used to house military personnel provided enough space for the documentary holdings which were growing day by day. 
Trace. If another inquiry about the same person was received later on, the file was continued. ${ }^{42}$

If neither a search in the Name Index with the associated search in the documentary holdings nor contact with the staff of the NTBs yielded any information about the whereabouts of a missing person, the case was forwarded to the zonal tracing bureaus which conducted an active search in the field for the missing person and for documents which could deliver information about their fate. Field searches usually started at the last place where the missing person was known to have resided. This might be a previous place of detention and persecution, but could also be a DP camp or some other place of residence after liberation. Knowledge about Nazi crimes was fragmentary in the immediate postwar period. Many of the camp locations were not known to the staff, who had to use maps and old gazetteers in order to locate them. It was important for staff to find out the correct location in order to be able to forward subsequent inquiries to the right zonal bureaus and local authorities. The zonal bureaus started off by searching their own documentary holdings before turning to local mayors, company owners or other survivors for information on the whereabouts of a missing person. The case of Polish national Stanisław Mróz is a good illustration of just how difficult it was to put the various pieces of the puzzle together. In 1944 the Germans deported him to Germany to perform forced labor. After the war his wife submitted an inquiry as to his whereabouts to the ITS. ${ }^{43}$ His last known place of residence was Amorbach which was located in the American zone. Because of this the zonal tracing bureau in the American zone of occupation was assigned the task of tracing Stanisław Mróz. Tracing staff went straight to Amorbach and checked various German Registration Offices located there, interviewing three Polish DPs and numerous companies as well. They described their efforts to trace him in a report to the ITS Headquarters:

Checks made at Amorbach with the various German Registration Offices failed to reveal any trace of person sought. There are 3 Polish Nationals still living at Amorbach (been in Amorbach all during the War) but none of them ever heard of a Mróz, Stanisław living in Amorbach. Gathering the names all employers [sic!] in Amorbach who at a time had employed, and are still employing foreign nationals, we checked each place but without success. ${ }^{44}$

42 Since 2018, all new files have been kept in digital form only.

43 Tracing inquiry from Maria Mróz, 28.1.1949, in: T/D file Stanislaw Mróz, 6.3.3.2/90584857/ITS Digital Archive, Arolsen Archives.

44 Tracing Report, 15.6.1949, in: T/D file Stanislaw Mróz, 6.3.3.2/90584853/ITS Digital Archive, Arolsen Archives. 


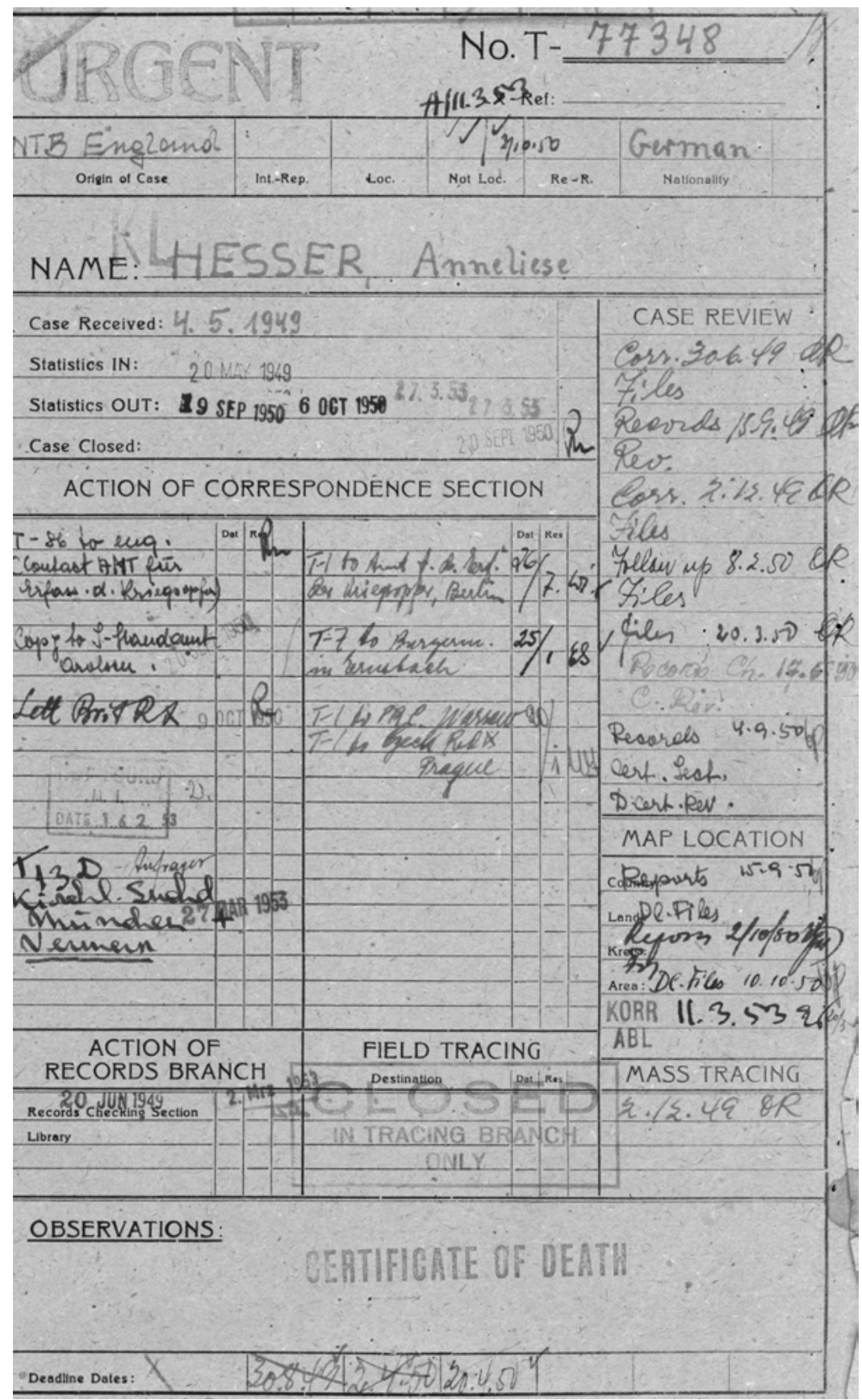

Fig. 5: Correspondence File, or T File, for Anneliese Hesser, 1949 (6.3.3.2/84699577/ITS Digital Archive, Arolsen Archives) 
As well as questioning people locally, the staff of the zonal tracing bureau also checked the index of the Wildflecken DP camp, one of the largest DP camps for Polish DPs in the American zone. This research revealed that Stanisław Mróz had been at Wildflecken for a short time after liberation. The tracing inquiry was then forwarded to the tracing team there.

Successful field searches were dependent on a number of factors: first, the ITS needed personnel with knowledge of various different languages, as shown by the above example involving knowledge of German and Polish. At the same time, staff needed to work in a structured, analytical manner in order to recognize interrelationships during the course of investigations and be able to understand them without assistance. One of the practical challenges which had to be faced was how to provide enough vehicles to be able to travel from camp to camp and from authority to authority. The staff of the zonal tracing bureaus wrote numerous letters complaining about the constant lack of vehicles, which put severe restrictions on their day-to-day work. Another obstacle to investigations was the short period of time spent by DPs in DP camps. This was due to the fact that many DPs set off to search for their relatives themselves or left the camps in order to be repatriated. Good cooperation with the German authorities was therefore indispensable. This is why targeted press campaigns were launched in an attempt to inform the public about how necessary and how difficult it was to trace missing persons as well as to encourage active public support.

At the same time, the media were also involved in mass tracing. This step in the tracing process was started "to search en masse for missing persons when there is too little information to institute individual search or when all other forms of search have failed." ${ }^{45}$ For this purpose, staff compiled lists of the names of missing persons, which they published in the media. The following key information was important for mass tracing campaigns: surname, first name, age, place and date of birth, last known address, and nationality. The search lists were sorted alphabetically and by nationality. The ideal procedure for mass tracing, which was not always strictly adhered to, consisted of three steps: first of all, staff sent the lists to the National Tracing Bureaus, tracing agencies, and DP camps, which put them on public display or broadcast them over loudspeakers. From June 1948 onwards, Jewish missing persons were registered on separate lists that were sent to Jewish relief organizations, such as the

45 Central Tracing Bureau, Brief Progress Report on the Mass Tracing Division, 15.2.1946, 6.1.1/ 82500734/ITS Digital Archive, Arolsen Archives. 
American Jewish Joint Distribution Committee (AJDC), or to Jewish communities. ${ }^{46}$ If the first step did not produce any results, the ITS moved on to the second step, which was to send the search lists to national and international newspapers. They were usually published wherever there was most hope of readers being able to provide information, for example in the place where the missing persons used to live. About 115 German newspapers and 30 DP newspapers received more than 140 search lists for publication per week. ${ }^{47}$ If this too failed to produce any information about the fate of a missing person, the third step was to broadcast the search lists on the radio. The lists were usually read out live initially, so hardly any recordings have survived.

One of the few recordings that still exist is an appeal that was broadcast by the BBC in August 1946. The program attempted to find relatives of children and adolescents who were believed to be in England. The program began with the following words: "Captive Children, an appeal from Germany." As well as broadcasting the personal details of the child survivor, the radio program also gave information on his or her path of persecution:

I call Katz, Salma Katz, who may be living in London. I call her on behalf of her 16-year-old cousin Hela Bergman, born in Poland, who was separated from her family at the age of 12 and made to work in an ammunition factory. Her father, mother, sister and brother were sent to Treblinka extermination camp. ${ }^{48}$

Radio stations in the zones of occupation were used for radio searches as well as radio stations in those countries with which there was close cooperation. The search lists were also broadcast on the ICRC's tracing program on Radio Geneva or on Vatican Radio. Between 1947 and 1950, about 5101 missing persons were found through mass tracing. At the beginning of 1948 about 190 people were being found every month. From 1949 onwards the number dropped month by month until at the beginning of 1950, about 80 people were still being found per month. Involving the public in tracing activities was a key search strategy that helped to integrate people from all over the world in the tracing process.

46 6.1.1/82505802/ITS Digital Archive, Arolsen Archives.

47 In 1949, as well as being sent to German newspapers, the search lists were also sent to one Polish newspaper in London, two Polish newspapers in Paris and one Jewish newspaper in the USA, see: International Tracing Service of IRO. Annual Report of the Director, 1949, 6.1.1/ 82505887/ITS Digital Archive, Arolsen Archives.

48 In 2014/2015, Axel Last traced the fate of 12 "child survivors" named in the 1946 broadcast. BBC Archive, London. Available at: https://www.bbc.co.uk/programmes/b0616npl/episodes/ player. Last accessed: 1.7.2019. 
German authorities too were to be encouraged to make an active contribution, as the opening credits of the UNRRA tracing broadcast show:

\begin{abstract}
We call all Allied and German agencies and authorities, we call the German police and all those who want to help us. We are appealing for information about the whereabouts of the people we are searching for as well as about the location of any documents or other records concerning foreigners which have not yet been requisitioned by the appropriate German authorities and forwarded to us. This UNRRA tracing service is only responsible for United Nations nationals, people who were forcibly deported and victims of political persecution. [...] Today's search list now follows. ${ }^{49}$
\end{abstract}

However, mass tracing did not only provide information on missing persons who survived, it also provided information on missing persons who had been murdered. On January 13, 1949, the Berliner Tagesspiegel newspaper published an appeal for information listing 39 names of missing Jewish men and women from Berlin. Josef Sander, a dentist in Berlin, wrote a letter to the ITS on the very same day explaining that he had read the appeal for information and had recognized a former patient, Charlotte Nachmann. He wrote: "The most important point I have to convey is the fact that, as a result of the barbaric measures taken by Hitler, the lady concerned is no longer alive because she was deported to the East in a transport of Jews back then." ${ }^{50}$ Mass tracing was often the last means staff had recourse to, while for many relatives it was the last hope they had of finding information about the whereabouts of a missing person. A letter from Irmgard Reicher, dated 30 October 1946, expresses this very vividly:

I have learned that my husband arrived in Auschwitz and suppose [sic] to have died there in August 1944. I cannot believe it. Therefore I kindly request you, from the bottom of my heart to have his name broadcasted in order learn the present whereabouts of my good husband. [...] The Radio Tracing Service of Radio Frankfurt/ Main I hear daily at 23.00 hours. ${ }^{51}$

Because the search for missing persons was often also a search for the dead, the town of Arolsen set up a special registry office in 1949 to issue death certificates for deceased concentration camp prisoners. ${ }^{52}$ Death certificates are still issued to

49 UNRRA tracing broadcast, Radio Stuttgart, 20.11.1946, F834411012, NDR, Hamburg.

50 Letter to the ITS from Josef Sander, 13.1.1949, in: T/D file Charlotte Nachmann, 6.3.3.2/ 92161085/ITS Digital Archive, Arolsen Archives.

51 Letter to the CTB from Irmgard Reicher, 30.10.1946, in T/D file Karl Reicher, 6.3.3.2/91699432/ ITS Digital Archive, Arolsen Archives.

52 Activities of the International Tracing Service during the second fiscal year (1st July 1948 - 30 June 1949), 6.1.1/82505800/ITS Digital Collection, Arolsen Archives. 
relatives to this day if a death that took place in a concentration camp can be documented on the basis of archival material from the Arolsen Archives or through research in registry offices and memorial sites.

\section{Standardization and Bureaucratization: Changes in the Way Information was Provided by the ITS}

Parallel to the search for missing persons, allied authorities also turned to the ITS in search of information for immigration and emigration proceedings in the postwar period. A marked change in working practices began to occur in the 1950s, when many of the inquiries concerned certificates of imprisonment or certificates of residence for West German compensation claims. ${ }^{53}$ The Federal Republic of Germany's policy on compensation and the critical analysis of Nazi crimes within German society were mirrored by the fluctuating waves of inquiries received by the ITS in the decades that followed. After a rise in inquiries related to compensation claims in the 1950s and 1960s, the ITS was deluged by a second major wave of inquiries which began in the late 1980s in the context of late debate in society on the Second World War and on victim groups which had not received compensation to date. This was particularly evident after the end of the Cold War, when it first became possible to enforce German compensation of victims of Nazi persecution from East-Central and Eastern Europe. Starting in 2000, there was a massive rise in inquiries in connection with payments made to former forced laborers under the Nazis through the Foundation "Remembrance, Responsibility and Future" (German acronym EVZ).

Responding to this type of inquiry relied more heavily on searching the ITS archive for documents related to specific individuals. If the information gleaned from the documentary holdings was not sufficient, staff would sometimes contact other bodies, such as insurance companies or local registration offices, for example. At the beginning of the 1950s, in close consultation with German compensation authorities and the legal representatives of former victims of Nazi persecution, the ITS developed a standardized procedure which was to be used for decades to come. In order to deal with the hundreds of thousands of inquiries connected with compensation or pension claims, the ITS created

53 Active field searches and mass tracing were discontinued in 1950. In 1954, inquiries pertaining to compensation amounted to $62.4 \%$ and thus exceeded the number of tracing inquiries. See: Achter Erfahrungsbericht des Internationalen Suchdienstes, 25.3.1955, 6.1.1/82508414/ITS Digital Archive, Arolsen Archives. 
standardized inquiry and response forms, one of which was the so-called certificate of imprisonment, for example. For the purposes of issuing these standardized certificates, a search was made in the ITS archive and the details contained in the Nazi documents were copied onto the certificates word for word, but the information given was not put into its historical context. Particularly in the 1950s and 1960s, this was problematic for many former persecutees, as the German Federal Law for Compensating Nazi Victims (German acronym BEG) stipulated that only those persons were entitled to receive a payment who had been "victims of violent National Socialist persecution for reasons connected with political opposition to National Socialism, race, religion or belief." 54 The information from Arolsen often provided the authorities with the grounds to exclude Sinti and Roma, homosexuals or so-called anti-social elements, and almost all nonGerman victims of Nazi persecution from receiving compensation. Up until 1955, the ITS still mentioned the problematic nature of the prisoner categories in the accompanying letters they sent out. In April 1955, the accompanying letters were discontinued, but the arbitrary nature of the assignment of prisoner categories was drawn to the attention of the Federal German authorities for the last time:

In many cases, concentration camp inmates were registered as 'professional criminals' as a consequence of criminal prosecutions on the basis of laws which have since been repealed. On the basis of the documents held by the ITS, it has been established that in many cases prisoners were registered as 'professional criminals' contrary to the provisions of Section 20a of the German Criminal Code..$^{55}$

The changes in the search process itself and in the provision of information in response to inquiries were also reflected in the new name given to the $T$ files, which were now known as $T / D$ files $-T / D$ denoting Tracing and Documentation.

Following the enactment of the Final German Federal Law for Compensating Nazi Victims in 1965, the number of inquiries received by the ITS continually declined. It was not until the late 1980s that there was another large increase in the number of inquiries. This resulted in an enormous backlog and waiting times that sometimes lasted years. To facilitate the search for information in the archive, a CNI fast-track procedure was introduced and digitization of the documentary holdings began. But despite these measures, the long waiting times re-

54 Federal Law for the Compensation of the Victims of National Socialist Persecution (Bundesentschädigungsgesetz BEG), 18.9.1953, section 1 (1). Available at: https://www.gesetze-im-inter net.de/beg/BEG.pdf. Last accessed: 2.7.2019.

55 Achter Erfahrungsbericht des Internationalen Suchdienstes, 25.3.1955, 6.1.1/82508415/ITS Digital Archive, Arolsen Archives. 
mained a major problem for the survivors, who were very elderly by then, and were widely criticized in the media at the time.

Most of the inquiries received today - around 20,000 per year - come from the descendants of former victims of Nazi persecution, primarily from Poland, Russia, Germany, the USA, France and Israel, who want to find out more about the fate of their relatives and reconstruct their family history. In order to answer their questions, research is conducted in the archive and digital copies of the archival documents are sent out together with explanatory information. But even today, new tracing cases are still sometimes opened and families are still being reunited. ${ }^{56}$

56 For information on the way information is provided today and on how the Tracing department of the Arolsen Archives provides support to people searching for information as well as on the type of inquiries submitted by the descendants of former victims of Nazi persecution, see the chapter by Ramona Bräu, Kerstin Hofmann and Anna Meier-Osiński in this volume. 